\title{
The Production of a Minas Frescal Prebiotic Cheese Obtained by Ultra Filtration, Enriched with Fibers
}

\author{
Nawal Krayyem Arbex ${ }^{* 1,2}$, Junio Cesar Jacinto de Paula ${ }^{2}$ and Denise Sobral ${ }^{2}$ \\ ${ }^{1}$ Gastronomy Faculty, Centro de Ensino Superior, Brazil \\ ${ }_{2}^{2}$ Instituto de Laticínios Cândido Tostes (ILCT)/Epamig, Brazil
}

Received: April 09, 2018; Published: April 18, 2018

*Corresponding author: Nawal Krayyem Arbex, Gastronomy Faculty, Centro de Ensino Superior, Juiz de for a, Instituto de Laticínios Cândido Tostes (ILCT)/ Epamig, Brazil, Email: nawalkrayyem@gmail.com

\begin{abstract}
The goal of this study is to review the current available ultra filtration of prebiotic cheeses and its many benefits to human health and gastronomy, and to propose its use at the production of a regional Brazilian cheese. Since the 1970s, many kinds of cheese were produced through ultra filtration. Thus, different kinds of cheese such as camembert, cream cheese, gorgonzola and others were successfully produced, assuring a high quality standard for them. An initiative in Brazil intends to produce a known regional kind of cheese, named 'Minas Frescal', through ultra filtration and to enrichen it with fibers, thus introducing a new industrial standard for this typical Brazilian cheese in the regional market of the State of Minas Gerais, homeland of this cheese.
\end{abstract}

Keywords: Cheese; Health; Prebiotic; Ultra Filtration; Brazilian Cheese

\section{Introduction}

Cheese is a versatile food and pleases various tastes [1]. It is rich in nutrients, rich in protein, fat, minerals, vitamins and trace elements (such as calcium, zinc and potassium) [2]. It can be used for direct consumption, together with wine [3], or as an ingredient in different recipes. Therefore, the functionality of cheese as a food is the subject of many previous studies [4,5]. This versatility makes it easier for cheese to be consumed by various social classes, age groups, when compared to other foods. There is also a great potential on using it as a 'functional food' [6]. Functional foods contain in their composition some biologically active substance that, when added to a usual diet, triggers metabolic or physiological processes, resulting in a reduction of disease risk and health maintenance [7].

\section{The Minas Frescal Cheese: Features and Importance}

Minas Frescal cheese is a fresh cheese, a product that has a wide commercial acceptance in all parts of Brazil. The whole country appreciates and consumes this product. It is an important part of the food habit of the Brazilian population, in most regions of the country, but especially in the Northeastern, Southeastern and Southern parts of Brazil [8]. In its physical features it presents a high content of humidity when compared to other cheeses. It shows a white mass, a soft consistency, a closed texture with some irregular glances, an a mild to slightly acidic taste. It is currently obtained by means of enzymatic coagulation of milk with addition of lactic acid or yeast. It is a fresh cheese, with no maturation and has a small shelf life (no longer than 20 days) [9].

The use of Ultra Filtration on the Production of the Minas Frescal Cheese

The production of 'Minas Frescal' cheese using retentates obtained from milk ultra filtration results in a higher yield and gives the dough a more solid and closed texture and a longer shelf life, as well as a uniform flavor pattern. As it is a cheese in which coagulation takes place in the packaging in which it is marketed, it is also a product in which the incorporation of fibers is easier [10] .Ultra filtration is a process of concentrating a fluid such as milk and it is forced to pass under pressure through a membrane that is semi permeable. This process generates a retentate that contains proteins, fats and colloidal mineral salts in greater proportions than that found in milk, and a permeate composed of water, minerals, lactose, non-protein nitrogen (NNP) and water-soluble vitamins (ROSENBERG, 1995) [11]. Therefore, for these benefits mentioned above, a Minas Frescal cheese enriched with fibers becomes a nutritional product with strong commercial appeal. 


\section{Prebiotics}

Prebiotics are no digestible food components that beneficially affect the host by selectively stimulating the proliferation or activity of desirable bacteria populations in the colon. Some examples of prebiotics that may be applied in dairy products are insulin, oligofructose, polydextrose, fructooligosaccharides and guar or Arabic gums. They modify the composition of the colonic microbiota in such a way that the bacteria with health promotion potential become the predominant majority. In addition, they can inhibit the multiplication of pathogens [12].

\section{Industrial Goal: to Produce a 'Minas Frescal' Cheese by Ultra Filtration in Brazil}

The goal is to produce a 'Minas frescal' cheese obtained by ultrafiltration with addition of prebiotic (inulin) and to evaluate its physical-chemical, sensorial and texture profile. It is hoped to obtain a healthy, commercially viable product that can be consumed by a large part of the population, in different age groups, adding nutritional values and taking into account the tendencies of the consumer market.

\section{Methodology}

\section{The Process of Milk Ultra Filtration and Cheese Making Should Work as Follows}

Integral, pasteurized and cooled milk will be heated to $55^{\circ} \mathrm{C}$ and concentrated to the volume concentration factor of 4: 1 , determined from the volume reduction obtained during the process and controlled by permeate flow measurements during the same process. After obtaining the desired concentration, the process will be stopped, the retentate removed from the system and thermally treated at $68^{\circ} \mathrm{C}$ for 10 minutes, followed by cooling to $32^{\circ} \mathrm{C}$ for the production of the cheeses. Immediately after the milk has been removed, the ultrafiltration system will be cleaned The retentate kept at $32^{\circ} \mathrm{C}$ in the cheese-making tank will be subdivided into three equal parts (A, B and C). Next, the salt, the fiber (to be chosen by means of pre-tests) and finally the coagulant will be added. The mixture will be homogenized for 1 minute and packed in polyethylene packages with a capacity of $0,50 \mathrm{~kg}$. After coagulation of the dough in the pots, the cheeses will be stored under refrigeration at $5^{\circ} \mathrm{C}$ for 28 days. Three different fiber concentrations will be tested and further analysis will be performed over time.

\section{Quality control}

a. Physical-chemical: $\mathrm{pH}$; titratable acidity; protein; fat; ashes; salt; moisture.

b. Sensory analysis: acceptance test.

c. Texture profile analysis (TPA).

d. Quantification of the fiber content in the final product.

\section{Conclusion}

Regarding its organoleptic features and its great commercial potential, the production of a Minas frescal cheese obtained by ultrafiltration and with the addition of fibers could be a landmark in introducing a new methodology of making quality food in Brazil. It would add the benefits of this healthy cheese to prebiotic features of adding fibers to it. This innovative process relies on high technology for producing a classical, traditional product through the lenses of a safe, well-known and reliable technique, the ultrafiltration in producing cheese. The international successful experiences with cheeses such as camembert, cream cheese, gorgonzola, all produced through ultrafiltration, could be expanded with the production of a typical Brazilian cheese according to high landmarks of quality and industrial production. More studies are yet to come, to access the viability of such a new product in the Brazilian market.

\section{References}

1. Mc Sweeney PLH (1997) The flavour of milk and dairy products: III. Cheese: taste. International Journal of Dairy Technology 50(4): 123-128.

2. Jenkins TC, Mc Guire MA (2006) Major advances in nutrition: impact on milk composition. Journal of Dairy Science 89(4): 1302-1310.

3. Harrington RJ, Mc Carthy M, Gozzi M (2010) Perceived match of wine and cheese and the impact of additional food elements: A preliminary study. Journal of Foodservice Business Research 13(4): 311-330.

4. Guinee TP (2002) The functionality of cheese as an ingredient: a review. Australian journal of dairy technology 57(2): 79-91.

5. Cruz AG, Buriti FCA, Souza CHB, Faria JAF, Saad SMI (2009) Probiotic Cheese: health benefits, technological and stability aspects. Trends in Food Science \& Technology 20(8): 344-354.

6. Silva RA, Lima MSF, Viana JBM, Bezerra VS, Pimentel MCB, et al. (2012) Can artisanal "Coalho" cheese from Northeastern Brazil be used as a functional food? Food chemistry 135(3): 1533-1538.

7. ANJO DFC (2004) Alimentos funcionais em angiologia e cirurgia vascular. Jornal Vascular Brasileiro 3(2): 145-154.

8. Rocha JS, Buriti FCA, Saad SMI (2006) Condições de processamento e comercialização de queijo-de-minas frescal Conditions of production and distribution of minas fresh cheese. Arquivo Brasileiro de Medicina Veterinária e Zootecnia 58(2): 263-272.

9. Ribeiro EP, Simões LG, Jurkiewicz CH (2009) Desenvolvimento de queijo minas frescal adicionado de Lactobacillus acidophilus produzido a partir de retentados de ultrafiltração. Revista Ciência e Tecnologia de Alimentos 29(1): 19-23.

10. Carvalho JDG, Viotto WH, Kuaye AY (2007) The quality of Minas Frescal cheese produced by different technological processes. Food Control 18(3): 262-267.

11. Rosenberg M (1995) Current and future applications for membrane processes in the dairy industry. Trends in Food Science \& Technology 6(1): 12-19.

12. Cardarelli HR, Saad SM, Gibson GR, Vulevic J (2007) Functional petitsuisse cheese: measure of the prebiotic effect. Anaerobe 13(5-6): 200207. 


\section{(C) (i) This work is licensed under Creative} Submission Link: https://biomedres.us/submit-manuscript.php

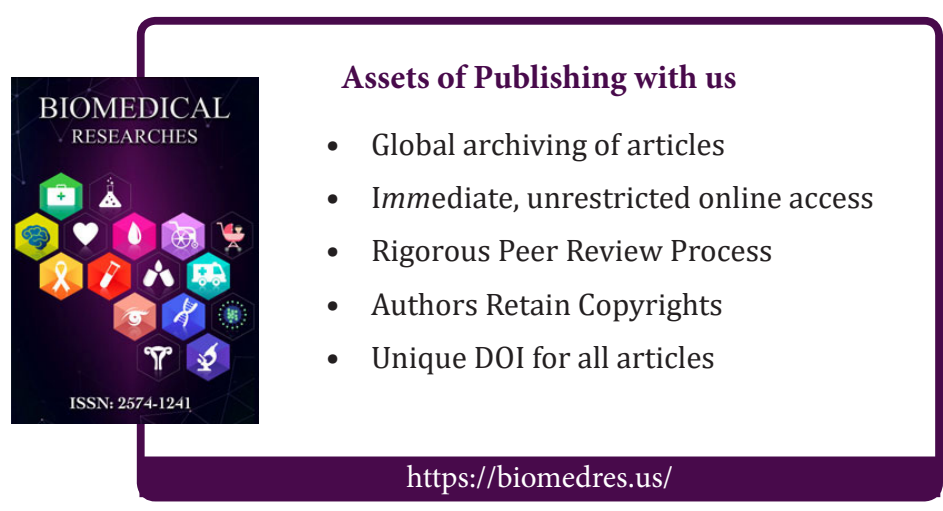

